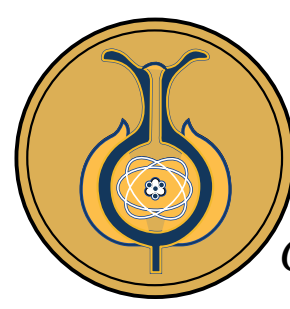

\title{
Knowledge of preservice elementary teachers on fractions
}

\author{
Conhecimento sobre frações de docentes do ensino fundamental em formação
}

Elena Castro-Rodríguez ${ }^{1}$ Luis Rico ${ }^{1}$

Received: Aug/4/2020 • Accepted: Sep/16/2020 • Published: Jul/31/2021

\section{Abstract}

In this paper, we studied the knowledge on didactic contents reflected by future elementary teachers when answering questions related to teaching and learning fractions. Following a qualitative methodology, specifically a case study, 9 senior pre-service elementary teachers were interviewed using a structured approach. The topic was presented to the subjects using a narrative they had previously written on how to initiate the concept of fractions with school children. After reading it, they were asked questions regarding task design, learning objectives, and mistakes and difficulties. Results identified two trends in the participants' knowledge: a procedural or technical trend in which the stated knowledge emphasizes procedures, processes, or action modes, and a conceptual or cognitive trend in which the stated knowledge emphasizes the functional understanding of fractions and their relationships. As a conclusion, it is essential that initial teacher training emphasizes mathematical as well as didactic contents.

Keywords: Didactic analysis; Pedagogical content knowledge; Didactic content; Preservice teacher training; Fractions; Mathematical knowledge; Mathematics education.

\section{Resumen}

En este trabajo profundizamos en el conocimiento sobre contenidos didácticos que futuro profesorado de primaria pone en juego al responder preguntas relativas a la enseñanza y el aprendizaje del concepto de fracción. Llevamos a cabo una metodología cualitativa, específicamente un estudio de casos. Realizamos entrevistas estructuradas a 9 estudiantes para docentes de primaria que estaban finalizando sus estudios universitarios. Para ello, introdujimos a los sujetos en el tema a través de una narración que ellos mismos habían realizado anteriormente sobre cómo iniciar a escolares en el concepto de fracción. Tras su lectura, planteamos preguntas relativas al diseño de tareas, objetivos de aprendizaje, y errores y dificultades. En los resultados identificamos dos tendencias en el conocimiento manifestado por los sujetos participantes. La primera de ellas es una tendencia procedimental o técnica en la que el conocimiento manifestado hace hincapié en llevar a cabo procedimientos, procesos o modos de actuación. En la segunda de las tendencias, conceptual o cognitiva, el conocimiento manifestado pone el énfasis en la comprensión funcional de las fracciones y sus relaciones. Concluimos que es fundamental que la formación inicial de profesorado haga hincapié tanto en contenidos matemáticos como en contenidos didácticos.

Elena Castro-Rodríguez, \ elenacastro@ugr.es, (D) https://orcid.org/0000-0002-2560-8982

Luis Rico, \1rico@ugr.es, (D) https://orcid.org/0000-0002-0366-5425

1 Departamento de Didáctica de la Matemática, Facultad de Ciencias de la Educación, Universidad de Granada, Granada, España. 
Palabras clave: Análisis didáctico; contenidos didácticos; conocimiento en contenidos didácticos, formación de profesorado; fracciones; conocimiento matemático; educación matemática.

\section{Resumo}

Neste trabalho aprofundamos no conhecimento sobre conteúdos didáticos que futuros docentes do ensino fundamental põem em jogo ao responder preguntas relacionadas com 0 ensino e a aprendizagem do conceito de fração. Executamos uma metodologia qualitativa, especificamente um estudo de casos. Realizamos entrevistas estruturadas com 9 estudantes para docentes do ensino fundamental que estavam finalizando seus estudos universitários. Para isso, introduzimos os sujetos no tema mediante uma narração que eles mesmos tinham feito anteriormente sobre como introduzir o conceito de fração com os estudantes. Depois da leitura, expusemos perguntas relacionadas com o desenho de tarefas, objetivos de aprendizagem, e erros e dificuldades. Nos resultados, identificamos duas tendências no conhecimento manifestado pelos sujeitos participantes. Na primeira delas é uma tendência procedimental ou técnica na qual o conhecimento manifestado enfatiza realizar procedimentos, processos ou modos de atuação. Na segunda das tendências, conceitual ou cognitiva, o conhecimento manifestado destaca a compreensão funcional das frações e suas relações. Concluimos que é fundamental que a formação inicial de docentes reforce tanto em conteúdos matemáticos quanto em conteúdos didáticos.

Palavras-chave: Análise didáctica; Conteúdos didáticos; Formação de docentes; Frações; Conhecimento matemático; Educação matemática.

\section{INTRODUCTION}

In the teaching of mathematics, a broad knowledge of school mathematical content does not guarantee good performance in instructional execution (Charalambous, 2016; Tirosh, 1999). Aware of this fact, the training of mathematics teachers has been and continues to be a field of growing attention in mathematics education research, which ultimately attempts to specify the necessary professional knowledge required for devising adequate preservice training plans (Sánchez, 2011; Tröbst, Kleickmann, Heinze, Bernholt, Rink \& Kunter, 2018).

The mathematical content necessary for mathematics teachers are delimited by the corresponding curriculum, which are normatively established through a detailed list of school mathematics topics. Part of this content corresponds to the didactic content of each topic in the curriculum as they are the object of teaching and learning (Rico, 2016). Didactic content is a relevant part of professional knowledge and must be included in preservice training plans. When planning to identify pedagogical content knowledge for a topic, it is unusual to possess a standardized program, with a list of topics, whose structure and articulation are explicit. Didactic content is not unequivocally characterized in mathematics education; it must be determined, validated and calibrated; that is to say, its extension and scope is based on investigations whose information, organization and derived results can be termed didactic contents of the topic.

Didactic content, although linked to specific topics of school mathematics, does not currently carry the same precision as mathematical content, it lacks explicitly structured normative regulation and 
appropriate technical documents. Furthermore, the expert groups do not appear to agree on the criteria for its recognition and acceptance. Therefore, delving in its study is of interest for its delimitation and inclusion in preservice training of teachers, and thus enable the improvement of the practice of elementary classroom mathematics.

The present study aims to contribute to the determination of specific didactic content that characterizes pedagogical content knowledge about fractions, systematize its study, and establish proposals for improving teacher training on this topic. Accordingly, we propose the objective of delving into the knowledge of teaching and learning as revealed by a group of preservice teachers upon answering a questionnaire related to the matter of pedagogical content knowledge. We base didactic content from a particular perspective of teaching practice, denominated didactic analysis (Rico, 2016). Specifically, we consider the design of tasks, the formulation of objectives and the detection of possible errors and difficulties encountered by schoolchildren (pupils) on the subject of fractions. We focus on the elementary notion of the concept of fraction that arises from the part-whole relationship, as this is the foundation and first approach to fractions (Behr et al, 1983; Kieren, 1993; Mack, 1990; Steffe \& Olive, 1990; Streffland, 1991).

\section{KNOWLEDGE OF PRE- SERVICE TEACHERS ON FRACTIONS}

Fractions are the basis and foundation of more advanced mathematical content (Lamon, 2005); however, research has shown that elementary school groups exhibit difficulty when dealing with fractions
(Behr, Wachsmuth, Post \& Lesh, 1984; Cramer, Post \& del Mas, 2002; Mack, 1990). To adequately address these difficulties, it is important that teachers have adequate knowledge on the subject matter and, therefore, of rational numbers. This has led to the development of studies focused on specific knowledge expressed by preservice teachers about fractions (D'Ambrosio \& Mendoca, 1992; Domoney, 2001), operations with fractions (Charalambous, Hill \& Ball, 2011; Isiksal \& Cakiroglu, 2011; Li \& Kulm, 2008), or regarding the equivalence of fractions (Marks, 1990). Said studies highlight the important limitations that teachers exhibit throughout preservice training, and that in many cases coincide with the difficulties displayed by the elementary school student population (Isiksal \& Cakiroglu, 2011). Furthermore, future teaching bodies interpret the fraction almost exclusively as a part-whole relationship (Domoney, 2001; Lo \& Grant, 2012), although they lack a clear understanding of this notion (Castro-Rodríguez, Pitta-Pantazi, Rico \& Gómez, 2016; Newton, 2008). However, recent studies add new approaches to research on the subject matter, identifying that teachers take advantage of their previous knowledge about fractions to develop new strategies and thus expand their knowledge (Whitacre, Atabaş \& Findley, 2019).

Previous works have analyzed the effects of preservice training on knowledge about fractions of future elementary school teachers (Rosli et al., 2020; Tröbst et al., 2018; 2019). These studies coincide in exhibiting that, although there is evidence of effects on content knowledge and pedagogical content knowledge, improvements in didactic knowledge were more consistent (Tröbst et al., 2018; 2019), even when instruction time dedicated to develop 
pedagogical content knowledge was less than that committed to content knowledge (Rosli et al., 2020). However, when the selected study sample under review were preservice secondary school teachers, contrary to the findings for preservice elementary school teachers, better results were observed regarding content knowledge than for didactic knowledge (Depaepe et al., 2015).

Focusing on specific didactic content, such as errors or teaching methodology, Şahin, Gökkurt \& Soylu (2016) found that both preservice teachers partially identify the errors committed by their students and that the correction method provided to amend such errors is based on the memorization of rules. Along the same lines, studies have been carried out that propose that future teachers analyze responses of schoolchildren to tasks of division of fractions (Adu-Gyamfi, Schwartz, Sinicrope \& Bossé, 2019) and proportional reasoning tasks (Jacobson, Lobato \& Orrill, 2018). The results of these works, contradictory to each other, suggest that the limits between content knowledge and pedagogical content knowledge are not clear. While, the work of Adu-Gyamfi et al. (2019) affirms that the limitations in the capacity of future teachers to analyze the responses of their students, interpret the strategies and act upon them, may be due to their didactic knowledge rather than content knowledge, Jacobson et al. (2018) highlight that teachers used their content knowledge to make sense of the responses provided by schoolchildren and that the possession of highly developed didactic knowledge was not reflected in the way that teachers use mathematical knowledge in teaching situations.

Mathematical representations and their use in the teaching of fractions have also been depicted in research as didactic content (Kang \& Liu, 2018; Lee \& Lee, 2019; Morris, Hiebert \& Spizter, 2009). Replicating the study by Morris et al. (2009), Kang and Liu (2018) focused on how future Chinese teachers propose to obtain an ideal response of their pupils when posed with the task of adding fractions, and what representation (manipulative material, graph paper, algorithm and pennies) is the ideal selection for solving a task of adding fractions. Unlike the results of Morris et al. (2009), the majority of pupils chose the algorithm problem as the most appropriate representation to solve the task; whereas among USA pupils the most popular option was the pennies problem followed by the graph paper problem. The reasoning behind a specific selection was given as one of pragmatic nature such as the required time for their resolution. Other types of representations are suggested by preservice elementary teachers in Lee and Lee (2019). In this work, the authors investigate how the participants perceived the use of representations in mathematics teaching and what representations they consider to overcome student errors in the learning of fractions. Their findings indicate the tendency to use few types of representations (area and length/ linear) and to do so in a procedural way.

Similar to the results obtained with preservice teachers, once the study subjects were in practice, the studies revealed them to possess limited knowledge about fractions and rational numbers (Jacobson \& Izsák, 2015; Klemer, Rapoport \& LevZamir, 2018; Lee, Brown \& Orrill 2011; Rojas, Flores \& Carillo, 2015). However, in comparison with preservice teachers, no significant differences have been identified in mathematical content knowledge between both groups, as is the case for specific didactic content, such as selection 
of tasks or selection and use of representations, which result easier for the practicing teachers (Charalambous, 2016).

In summary, previous studies focused on evaluating the knowledge about fractions and rational numbers of preservice (Depaepe et al., 2015; Tröbst et al., 2019; Şahin et al., 2016) or practicing teachers (Jacobson \& Izsák, 2015; Klemer et al., 2018; Lee, Brown \& Orrill 2011; Rojas et al., 2015), and highlight the shortcomings they present. In order to overcome these deficiencies, it is necessary to improve training by delimiting the contents that must be part of it (Wu, 2018). In this study we intend to contribute to the improvement of this problem, addressing the knowledge about fractions, from a perspective of teaching practice termed didactic analysis (Rico, 2016).

Specifically, by using didactic analysis, we intend to elucidate basic aspects related to didactic content of fractions by extending the knowledge related to the design of tasks, learning objectives and limitations manifested by preservice teachers on the concept of fraction.

\section{DIDACTIC ANALYSIS}

By didactic analysis of the mathematics content of an elementary education curriculum we understand a "method to analyze, structure and interpret, within a curricular framework, the didactic contents of school mathematics, with the purpose of its planning and implementation in the classroom and its evaluation" (Rico, 2016, p. 96). In turn, didactic analysis structures a system of four analyses, designated as:

- Content analysis: focused on the meanings of school mathematics content.
- Cognitive analysis: determines the intentionality and the conditions for the achievement of learning for those same contents.

- Instruction analysis: considers the choice of tasks, their organization and resources necessary for teaching the content.

- Evaluation analysis: assesses the learning achieved, the information collected and the decision-making process.

Each of these analyses is based on a specific curricular dimension, has its own object of study and consists of a system of organizing components. The didactic content of each topic of school mathematics is described by these organizing components. The need for a methodology for the design and performance of our study led us to select didactic analysis as a tool (Rico, 2016). In particular, this work has used the components of cognitive analysis as categories by which we identify, classify, and interpret the responses of preservice teachers related to the learning of fractions at the elementary school level.

\section{Cognitive analysis}

Once the level, cycle and school content have been established, cognitive analysis attempts to organize the justification and scope of the topic to be learned (Rico, 2016). According to Lupiáñez (2013):

Cognitive analysis is structured around what the teacher expects schoolchildren to learn, what can interfere with that learning, and what allows schoolchildren to learn and the teacher to observe whether that learning occurs effectively. (p. 90) 
Consequently, when carrying out this type of analysis for a given mathematics content, the corresponding didactic content is identified as comprising of:

- Objectives, competencies, and commitments: which define and organize what the teachers propose and expect pupils to learn about fractions as a part-whole relationship, according to the established level or levels.

- Limitations in learning: which focus on the possible errors that pupils may incur when working with fractions as a part-whole relationship, the difficulties on which these errors may be based and the blockages that may arise in the pupil's learning process.

- Demands or challenges: with the design of tasks, as the main vehicle to provide learning opportunities to the school population.

\section{METHOD}

To answer the questions posed in the investigation, we follow a case study methodology by conducting individual interviews. Specifically, it is an instrumental case study, since we try to delve into the wealth of information provided by the study subjects in its diversity and scope, we do not seek quantity or to standardize the gathered information (Stake, 2010).

\section{Study subjects}

In this study, the 9 participating undergraduate preservice elementary teachers coursed the last year of the Grado de Maestro de Educación Primaria (translated as Elementary Teacher Degree) program at the University of Granada, Spain. They took three mathematics courses during their university formation. The first course focused on the study of the content of school mathematics. The second focused on teaching and learning facets of the different thematic nuclei of school mathematics concretized in cognitive and didactic aspects. The third course was oriented to the study of the mathematics curriculum assigned to Primary Education and the design of didactic units for this stage of education.

The study subjects were selected from a broader group of 82 students who had participated in a previous study (Castro-Rodríguez et al., 2016), where the subjects were categorized according to their specialized knowledge of the content of the part-whole relationship. The 9 participants were selected for belonging to each of the study subjects categories.

\section{Data collection and instrument}

Data collection was carried out through individualized personal interviews with each participant. The interviewer had a structured scripted questionnaire to be applied with the participants. First, the interview introduced them to a teaching-learning situation regarding fractions. For this, each subject was given a narrative that each participant had previously written on how to introduce the concept of fractions to school groups. After reading the narrative, we asked questions related to three topics of didactic content: task design, objectives, and errors and difficulties (Table 1). Among different didactic content topics, we focus on these three, because we believe they are fundamental for the planning of teaching processes (Lupiáñez, 2009). 
Table 1. Interview questions

\begin{tabular}{ll}
\hline \multicolumn{1}{c}{ Pedagogical content knowledge } & \multicolumn{1}{c}{ Question asked } \\
\hline Task design & $\begin{array}{l}\text { To introduce the concept of fractions to your pupils, propose a task, } \\
\text { activity or problem that complements the class sequence you created. }\end{array}$ \\
Formulation of objectives & $\begin{array}{l}\text { By executing the class sequence and putting the tasks you created into } \\
\text { practice with your pupils, what do you think your pupils will learn? }\end{array}$ \\
Identification of errors and difficulties & $\begin{array}{l}\text { (Errors) In what can pupils make errors when performing the task? } \\
\text { (Difficulties) Why do you think pupils make error? }\end{array}$
\end{tabular}

Note: Own source from the present investigation.

\section{Procedure}

The interviews were conducted individually, in an isolated room to assure optimum sound of the audio recording. The interviewer was the imparting professor of the course "Design and development of the mathematics curriculum in Primary Education" that the study subjects were taking at the time of the interview. The relationship of trust that the study subjects had with the interviewer allowed a natural environment during the process, as well as obtaining their collaboration. To detect possible errors in the design and application of the interview, a pilot interview was carried out with two individuals, three weeks prior to conducting the final interviews. After the pilot, the tasks and questions were revised to a clear and appropriate final version without further modifications.

\section{Data analysis}

The interviews were audio-recorded and later transcribed for analysis. We performed a qualitative analysis, specifically a content analysis, of the responses for each of the questions posed for the topics of task design, objectives, and errors and difficulties (Krippendorff, 1990). For this, we rely on the categories developed in the work of Lupiáñez (2009) where didactic content was analyzed in didactic units of a given topic of school mathematics.
First, the responses to the task design were analyzed according to the structure of the part-whole relationship present in the statement.

Second, for the formulation of objectives, the categories of cognitive capacity and content type were considered. The first category, cognitive capacity, refers to the degree of precision in stating the capacity that the student body is expected to acquire and which may be related to the performance of actions or the manifestation of behaviors. We assign three values to this variable: imprecise, defined and elaborate. We code the objective as imprecise when the provided statement does not expressly mention a capacity (because it is a purely mathematical statement) or is too generic. If the statement of the objective embraces a cognitive capacity through a singular type of action, it is coded as defined; whereas, if it involves more than one capacity, it is coded as elaborate.

The second category, content type, distinguishes the conceptual field from the procedural field. Thus, in the statements of the objectives, we distinguish three values for this variable, those that in the component of mathematical content refer to conceptual aspects, those that refer to procedural aspects, or those that refer to both aspects. It should be noted that we have not found any objective whose statement refers to the attitudinal field. 
Finally, the responses regarding learning limitations were first analyzed according to difficulty-type. This variable examines whether the statement corresponds to an error, a difficulty, an obstacle, lack of knowledge or if it does not constitute a limitation. Depending on the value of the variable limitation type, the response was analyzed according to the variable difficulty type or error type.

The variable difficulty type, according to the categories defined by Socas (1997), takes values (a) associated with the complexity of mathematical objects, (b) associated with processes inherent to the mathematical activity, (c) associated to teaching processes, (d) associated with the students' cognitive development processes, (e) associated with affective attitudes and (f) emotional attitudes towards mathematics.

The variable error type is based on the categories defined by Movshovitz-Hadar, Zaslavsky and Inbar (1987). This variable takes the values (a) misused data, (b) incorrect interpretation of the language, (c) logically invalid inferences, (d) distorted theorems or definitions, (e) lack of verification of the solution, (f) technical errors, and (g) it does not constitute an error.

\section{RESULTS}

We present the results, organized according to the three cited components, namely the design of tasks, formulation of objectives, and identification of errors and learning difficulties.

\section{Task design}

Regarding the task design component, all study subjects were able to propose, in a natural way, some type of task. The tasks posed by participants were analyzed taking into account the structure of the part-whole relationship present in the statement. Table 2 exhibits the tasks stated by the participating study subjects.

Table 2. Tasks proposed by the participating study subjects

\begin{tabular}{cl}
\hline Participant & Proposed task \\
\hline S1 & $\begin{array}{l}\text { We are on our way to the science park and we have taken a straight route to get there faster. } \\
\text { When we encounter the first traffic light, we have traveled } 1 / 3 \text { of our way. How much further to } \\
\text { complete our route if there are no more traffic lights? }\end{array}$ \\
S2 & $\begin{array}{l}\text { If we cut a cake into } 4 \text { slices and I have eaten } 3 / 4 \text { of the cake, how many slices remain? Ex- } \\
\text { press it as a fraction. }\end{array}$ \\
S3 & $\begin{array}{l}\text { We have too big a rope. We want to divide the rope for } 3 \text { people so that each person gets a } \\
\text { piece of the rope, the pieces must be the same size, what part of the rope will I get? }\end{array}$ \\
S4 & $\begin{array}{l}\text { If Carlos has a cake and wants to share it equally with his } 6 \text { friends, represent as a fraction } \\
\text { how you would go about sharing the cake. }\end{array}$ \\
S5 & $\begin{array}{l}\text { Marta forgot her snack for recess, but her friend Daniel decides to share. If Daniel has divided } \\
\text { his snack into } 3 \text { pieces and has eaten } 2 \text {, what part of the snack has Marta eaten? }\end{array}$ \\
S6 & $\begin{array}{l}\text { Carolina baked a chocolate cake for my birthday, if there are } 6 \text { of us and we divide it into } 6 \\
\text { equal slices and I eat the first slice, how many slices of cake are left? Make a drawing. }\end{array}$ \\
S7 & $\begin{array}{l}\text { We have a colored ribbon that was bought by } 3 \text { friends, what part would correspond to each } \\
\text { friend? }\end{array}$ \\
S8 & $\begin{array}{l}\text { My mother divides the biscuit into } 3 \text { equal parts. If my brother eats two-thirds of the biscuit, } \\
\text { how much is left for me to eat? }\end{array}$ \\
S9 & $\begin{array}{l}\text { In her house María has a loaf of bread which is divided into three pieces. If she eats } 1 / 3 \text { of the } \\
\text { loaf, how many pieces of bread are left for her sister and mother? }\end{array}$ \\
\hline
\end{tabular}

Note: Own source from the present investigation. 
The tasks designed by the participants were, in all cases, problem statements, that is, the description of a part-whole relationship followed by a question. In general, the tasks can be considered appropriate as an introductory theme to the concept of fractions, with the exception of the statement made by subject S6, who proposed a statement of additive structure of change. In all cases, the study subjects present, first, the whole or unit, in some cases fractionated, and then request from the pupils the result of a distribution (S3, S4 and S7) or the calculation of the complementary fraction, or complementary parts. In the latter case, different options are presented: (a) given a fraction, the complementary fraction is requested ( $\mathrm{S} 1, \mathrm{~S} 2, \mathrm{~S} 8)$, (b) given a fraction, the number of remaining parts is requested (S9), or (c) given one or more parts, the fraction of the remaining parts is requested (S5).

\section{Learning objectives}

By formulating the learning objectives, the study subjects expressed the knowledge, capacities and attitudes expected to be achieved, mastered and applied by pupils upon receiving the teachers' explanation on how to introduce the concept of fractions. All preservice teachers manifested some type of objective, which are collected and presented in Table 3. Following the teachings of Lupiáñez (2009), the analysis of the obtained answers considered two categories namely, cognitive capacity and content type.

The majority of the study subjects did not encounter excessive difficulties in stating learning objectives associated with their narrative. With regard to the first variable, cognitive capacity, participant S2 was the only one who formulated a generic objective "learn about fractions". Three of the study subjects (S1, S6 and S8) raised elaborate objectives, the expression of which includes two capacities

Table 3. Objectives formulated by participating study subjects

\begin{tabular}{|c|c|c|c|}
\hline Participant & Objective posed & Capacity & Content type \\
\hline S1 & $\begin{array}{l}\text { Learn to differentiate the parts that we have or take from the } \\
\text { whole. }\end{array}$ & Elaborate & Both \\
\hline & How to distribute a route into 3 sections. & & \\
\hline S2 & Learn about fractions. & Generic & Conceptual \\
\hline S3 & Learn about fractions by dividing a rope into equal parts. & Specific & Conceptual \\
\hline S4 & Know how to represent (not solve) a statement about fractions. & Specific & Procedural \\
\hline S5 & $\begin{array}{l}\text { Learn to deal with fractions in everyday life situations, to use } \\
\text { them in everyday life and learn their usefulness, even if pupils } \\
\text { do not express it in writing. }\end{array}$ & Specific & Conceptual \\
\hline S6 & Learn to divide in an exact and creative way. & Elaborate & Both \\
\hline S7 & $\begin{array}{l}\text { Understand the partition of things, time, objects, food, etc. } \\
\text { To first understand fractions by employing simple, real-life } \\
\text { language and scenarios where pupils find the use of fractions } \\
\text { useful. }\end{array}$ & Specific & Conceptual \\
\hline S8 & $\begin{array}{l}\text { Divide an object into equal parts. } \\
\text { Learn that the sum of all the parts represents the whole of what } \\
\text { was initially present. }\end{array}$ & Elaborate & Procedural \\
\hline S9 & $\begin{array}{l}\text { Be able to master operations involving fractions, in this case } \\
\text { mastery of subtraction. }\end{array}$ & Specific & Procedural \\
\hline
\end{tabular}

Note: Own source from the present investigation. 
situated in independent sentences: "Divide an object into equal parts. Learn that the sum of all the parts represents the whole of what was initially present'. The rest of the study subjects raised specific objectives that expressed a single cognitive capacity.

In the variable content type, objectives related to conceptual and procedural knowledge are observed, such as "Understand the partition of things, time, objects, food, etc." and "Divide an object into equal parts", respectively. The table above shows that neither of the two types of content predominates in the responses of the participating subjects. Only two participants S1 and S6 raised elaborate objectives that consider both types of knowledge, conceptual and procedural, in their responses.

With respect to knowledge referenced by the objectives, six of the cases correspond to knowledge based on the part-whole relationship and are also related to the proposed contexts: "divide an object" (S3, S6 and S8), "distribute" (S1), "differentiate the parts from the whole" (S1) and "recognize that the sum of all the parts correspond to the whole" (S8). Some of these objectives: "recognize that the sum of all the parts correspond to the whole" and "distribute" are directly related with the structures of the proposed tasks in the previous question, while "divide an object" or "differentiate the parts from the whole" are more general and fit any of the contexts.

Only S9 expressed an objective unrelated to the introductory theme to the concept of fractions, which made reference to operations, particularly the subtraction of fractions.

\section{Limitations: Errors and difficulties}

In the last question regarding learning limitations, the participating study subjects reflected on the errors that pupils may incur when carrying out their tasks and the difficulties originating therefrom. These responses are presented in Table 4.

Table 4. Responses given by participating study subjects regarding limitations

\begin{tabular}{|c|c|c|}
\hline Participant & Responses about errors & Responses about difficulties \\
\hline $\mathrm{S} 1$ & $\begin{array}{l}\text { Confusion when it comes to } \\
\text { knowing what place each piece of } \\
\text { data occupies in the subtraction. }\end{array}$ & $\begin{array}{l}\text { Divide the path. } \\
\text { Divide the path into three equal parts and choosing one. }\end{array}$ \\
\hline $\mathrm{S} 2$ & $\begin{array}{l}\text { That they (pupils) do not know } \\
\text { how to solve it or if they solve } \\
\text { it, they would write something at } \\
\text { random. }\end{array}$ & $\begin{array}{l}\text { Because it is complex, if I have } 4 \text { slices, instead of seeing } \\
4 \text {, I can see it as } 4 / 4 \text { although I know that the result is } 1 \\
\text { which represents the whole. Thus I can say I have } 4 \text { slices } \\
\text { and I have eaten } 3 / 4,4 \text { minus } 3 / 4 \text { and the pupil could write } \\
\text { something at random. } \\
\text { We must teach them that if a cake is comprised of } 4 \\
\text { pieces, it represents the whole cake which is equal to } 4 / 4 \text {. } \\
\text { Thus, if the pupil is not taught so, he or she will write } \\
4-3 / 4 \text { consequently leading to err. }\end{array}$ \\
\hline S3 & $\begin{array}{l}\text { Dividing a unit among three } \\
\text { because it is an odd number. }\end{array}$ & $\begin{array}{l}\text { Because working with odd numbers always create more } \\
\text { problems than with even numbers, even numbers are better } \\
\text { perceived by boys and girls. Dividing a unit by an even } \\
\text { number is better associated than dividing by odd numbers. } \\
\text { Because if you divide } 4 \text { by } 2 \text { you know you get equal } \\
\text { parts... however, } 1 \text { divided by } 3 \text { equals zero point some- } \\
\text { thing, and this zero point something may be unmanageable } \\
\text { by the pupils. Boys and girls find it easier to divide a unit } \\
\text { by an even number than by an odd number. }\end{array}$ \\
\hline
\end{tabular}




\begin{tabular}{cll}
\hline Participant & \multicolumn{1}{c}{ Responses about errors } & \multicolumn{1}{c}{ Responses about difficulties } \\
\hline S4 & $\begin{array}{l}\text { When adding, they would also } \\
\text { add the denominators thus claim- } \\
\text { ing to obtain 6/36. }\end{array}$ & $\begin{array}{l}\text { Due to carelessness (mistake), because even if the teacher } \\
\text { has given a previous explanation to them... often times } \\
\text { pupils are focused on the result of the upper section } \\
\text { (numerator) of the fraction, forgetting about the lower }\end{array}$ \\
& & $\begin{array}{l}\text { section (denominator), this has happened to me many } \\
\text { times. So much emphasis is given by pupils with adding }\end{array}$ \\
& & \\
& & \\
& & \\
& &
\end{tabular}

S5 Failure in comprehension. Instead Because there is failure in reading comprehension. of dividing the snack in three equal parts, it would be divided in two, since there are two children to be treated.

S6 Dividing into equal parts and without pupils really seeing what they are taking or giving.

Perhaps the rule of measures...there I see lots of carelessness, when you ask (a pupil) to divide a cake into three equal parts, but each pupil cuts it however he or she pleases. There is no correct way of dividing the cake so as to later obtain a correct solution, therefore...pupils do not perform an exact division of the cake and proceed but divide it at will. It is necessary to use measures, rules...

S7 The graphical correspondence of the three parts each belonging to one third. Dividing the unit in three parts does not result difficult for the pupils, but more the graphical to numerical correspondence.

S8 In the placement of the fractions when subtracting. Because it is not as graphical...it is more of reasoning, and they truly have to comprehend fractions, if they do not comprehend fractions they will be unable to perform the equivalence between the graphical and numerical.

When seeing fractions, when seeing one number on top of another it is not thought that they are normal subtractions, pupils may think that this $(2 / 3)$ is greater than this $(3 / 3)$. Upon seeing the fractions they may confuse the numbers and may think that number order placement is indifferent.

S9 The pupils could have difficulty Because I have not specified how they should do it, I have when stating the problem without the fractions and doing it with them, perhaps they could also stated that I have three parts and that they can directly remove two and done, I have not stated that I have 3 out of 3 and that if I remove one I would then have $2 / 3$. show difficulties with the operation and make mistakes with the numerator and denominator. Also, because they may not fully understand the problem statement and perform the simple operation without obtaining the result through the use of the fractions.

Note: Own source from the present investigation.

The responses given to the question about errors and to the question about difficulties, collected in Table 4, were first analyzed according to the variable difficulty type. This variable examines whether the statement corresponds to an error, a difficulty, an obstacle, lack of knowledge or if it does not constitute a limitation. Depending on the value of the variable limitation type, the response was analyzed according to the variable difficulty type or error type. Table 5 summarizes the analysis of the responses to the questions on learning limitations, according to the variables defined above. 
Table 5. Responses regarding limitations

\begin{tabular}{clll}
\hline Participant & \multicolumn{1}{c}{ Limitation type } & \multicolumn{1}{c}{ Error type } & \multicolumn{1}{c}{ Difficulty type } \\
\hline S1 & Error and difficulty & Misused data & $\begin{array}{l}\text { Processes inherent to mathematical } \\
\text { activity }\end{array}$ \\
S2 & Lack of knowledge & \\
S3 & Difficulty & Complexity of mathematical objects \\
S4 & Error & Technical error & \\
S5 & Error and difficulty & Misused data & Cognitive development processes \\
S6 & Error and difficulty & Distorted theorems or definitions & $\begin{array}{l}\text { Processes inherent to mathematical } \\
\text { activity }\end{array}$ \\
& Difficulty & & Complexity of mathematical objects \\
S8 & Error & Technical error & \\
S9 & Difficulty & & $\begin{array}{l}\text { Processes inherent to mathematical } \\
\text { and teaching activities }\end{array}$ \\
\hline
\end{tabular}

Note: Own source from the present investigation.

As can be seen in the table above, the participating study subjects found limitations and lacked fluency when asked to disclose possible errors that may be incurred by pupils in performing the proposed tasks and in justifiably linking such errors to the difficulties that could eventually stem therefrom. Some participating subjects did not formulate errors and difficulties, others formulated very generic difficulties or limited themselves to repeating the same response given to the question about errors.

Regarding raised errors, participants made reference to technical errors or poorly formulated data due to possible failures in the algorithms employed for adding and subtracting fractions, despite the fact that in no task it is necessary to carry out such operations for their resolution. Other cited errors, ascribed to distorted definitions of the concept of fraction, was the inequality of the parts when dividing the whole unit and, relative to misused data, dividing the whole into an incorrect number of parts.

The responses provided regarding difficulties focus on the processes inherent to mathematical activity, particularly the processes of division and distribution, processes of cognitive development with problems in reading comprehension, teaching processes cause by instructors' inability to correctly teach task resolution, and difficulty of mathematical objects due to the relationship between the graphical and numerical representations of the fractions. The responses of study subject S2 stand out, because he or she was the only one to answer the questions about limitations citing lack of knowledge "that they (pupils) do not know how to solve it or if they solve it, they would write something at random".

\section{DISCUSSION AND CONCLUSIONS}

Didactic contents, as part of preservice training, needs to be studied and set into practice in the teachers' initial training, not only from a general point of view, but also taking into account the idiosyncrasies of the content areas, such as school mathematics. From a general point of view, detailed analyses have been carried out, however, in aspects relative to the specificity of the areas of content, much work remains to be done (Wu, 2018). The present study, in addition 
to providing information with which to contribute to bridging this deficiency in knowledge and seeking the practical improvement of preservice teacher training, shows a way to overcome difficulties reported in other studies (D'Ambrosio \& Mendonça-Campos, 1992; Li \& Kulm, 2008; Marks, 1990), wherein deficiencies in the content on fractions affected their results. Our approach, through cognitive analysis, delves in the study of tasks, objectives, and errors and difficulties present in the learning process proposed by preservice elementary teachers has made possible to overcome some of the aforementioned difficulties.

Among the results obtained regarding the design of tasks, we highlight that the participating study subjects proposed in all cases, the disclosure of problems encountered upon being requested to propose, in a spontaneous manner, a task involving fractions. Likewise, the majority of the study subjects were able to disclose objectives specific to the topic. These objectives refer to procedural and conceptual contents, and aspects such as dividing different types of objects and the usefulness of fractions. We thus consider that the assessed study group showed adequate capacities. In this regard, we emphasize that in their second year of university formation, all study subjects took a course on teaching and learning of mathematics wherein these aspects were addressed and from where they can advantageously draw upon acquired content knowledge and pedagogical content knowledge, as suggested by Whitacre et al. (2019).

The study of learning limitations is seen from another perspective. Despite the fact that the study subjects were able to spontaneously exemplify tasks suitable for learning the fractions written in the form of problem statements, they had difficulties in finding possible errors that pupils may incur in such tasks and in justifiably linking the errors to the difficulties originating them. Of the 9 study subjects, only 5 raised errors, mainly resorting to technical errors referring to failures in the algorithms employed for adding and subtracting fractions. This coincides with the results obtained by Şahin, Gökkurt and Soylu (2016), where preservice teachers partially identified student errors and the correction method was based on the memorization of rules. From this finding, we consider that the participating group of preservice teachers were unable to develop this capacity during their training, thus it is pertinent that personnel responsible for preparing preservice teacher training programs take this aspect into account as an advantageous capacity to incentivize in the professional development of future teachers.

As a balance of the results, in the data sets obtained in the interviews, we identified two trends in the knowledge about the teaching and learning of the concept of fraction manifested by the subjects participating in the study. The first of these is a procedural or technical trend $(\mathrm{S} 4, \mathrm{~S} 8$ and S9) in which the knowledge expressed emphasizes carrying out procedures, processes or modes of execution. In particular, this trend groups together participants who set procedural objectives such as "dividing an object into equal parts" or "mastering operations with fractions" and who, with respect to limitations, identified technical errors or difficulties associated with the processes inherent to mathematical activity, mainly related to operations with fractions such as "when adding fractions, they would add the denominators", "in the placement of the fractions when subtracting". The second trend is a conceptual one (S3, S5 and S7) 
wherein the manifested learning knowledge emphasizes the functional comprehension of fractions and their relationships. This tendency is formed by study subjects who disclosed applied or conceptual type objectives such as "learning the usefulness of fractions" or "learning fractions from the division of a rope" and difficulties associated with the complexity of mathematical objects and the cognitive development of students. Study subject S2 stands out for presenting responses distant from the two previous trends. His or her stated objective "learn about fractions" and awareness of the limitation relative to the lack of knowledge "that they (pupils) do not know how to solve $i t$ " reflects his or her endowment of generic knowledge about the learning of fractions. Our results expand previous findings where it was only detected that preservice elementary teachers tend to manifest pragmatic or procedural knowledge (Kang \& Liu, 2018; Lee \& Lee, 2019). One possible explanation for the above is the way in which the questions were applied in these studies, formulating area and part-whole representations as stimuli (Lee \& Lee, 2019) and providing selection among various options (Kang \& Liu, 2018), which could limit and condition the offered responses.

Despite the results obtained, the present study is not without limitations. Our analysis did not include data describing the received training, as this affects the way in which the participating study subjects respond to the delivered questions. Another limitation of our research is related to the size of the sample, which limits the possibility of generalization.

Teaching knowledge is essential to guarantee adequate teaching of mathematical topics. In the case of fractions, among the different problems associated with its teaching, the dependence on textbooks (which usually present errors in the topics of fractions) and the variety of meanings of the notion of fraction stand out (Wu, 2018). In order to overcome these problems, it is essential that teachers possess an adequate knowledge of the topic and, therefore, preservice training courses must thoroughly reflect and delimit the necessary content. Coinciding with other studies (Charalambous, 2016; Lupiáñez, 2013; Rico, 2016), we consider essential that initial teacher training emphasizes not only mathematical content, but also didactic contents, such as learning limitations. Furthermore, as revealed by research (Rosli et al., 2020; Tröbst et al., 2018; 2019), specialized courses that focus on the development of these contents, cause significant improvements in the didactic knowledge of teachers. For this, didactic analysis provides a classification system, structured around conceptual, cognitive, normative and social dimensions, useful for delimiting the didactic contents suitable for preservice teacher training.

\section{ACKNOWLEDGMENTS}

This investigation was prepared with the assistance from project PCG2018095765-B-100 of the Plan Nacional of $\mathrm{I}+\mathrm{D}+\mathrm{I}$ (MICIN) (translated as National Plan of $\mathrm{R}+\mathrm{D}+\mathrm{I}(\mathrm{MICIN})$ ) and from Plan Andaluz de Investigación, Desarrollo e Innovación (Grupo FQM-193, Didáctica de la Matemática. Pensamiento Numérico) (translated as Andalusian Plan of Research, Development and Innovation (Research Group FQM-193, Didactics of Mathematics. Numerical thinking)). 


\section{AUTHORSHIP CONTRIBUTION DECLARATION}

The percentage distribution regarding the contribution for the conceptualization, preparation and correction of the present article is disclosed as follows: E.C.R. $60 \%$ and L.R. 40\%.

\section{DECLARATION OF AVAILABILITY OF DATA}

Data supporting the results of this study will be made available by author E.C.R. upon reasonable request.

\section{REFERENCES}

Adu-Gyamfi, K., Schwartz, C. S., Sinicrope, R. and Bossé, M. (2019). Making sense of fraction division: domain and representation knowledge of preservice elementary teachers on a fraction division task. Mathematics Education Research Journal, 31, 507-528. https:// doi.org/10.1007/s13394-019-00265-2

Behr, M. J., Lesh, R. Post, T. R. and Silver, E. A. (1983). Rational number concept. En R. Lesh y M. Landau (Eds.), Acquisitions of Mathematics Concepts and Processes (pp. 91-126). Academy Press.

Behr, M. J., Wachsmuth, I., Post, T. R. and Lesh, R. (1984). Order and equivalence of rational numbers: A clinical teaching experiment. Journal for Research in Mathematics Education, 15(5), 323-341. https://doi.org/10.2307/748423

Castro-Rodríguez, E., Pitta-Pantazi, D., Rico, L. and Gómez, P. (2016). Prospective teachers' understanding of the multiplicative part-whole relationship of fraction. Educational Studies in Mathematics, 92(1), 129-146. https://doi. org/10.1007/s10649-015-9673-4

Charalambous, C. (2016). Investigating the Knowledge Needed for Teaching Mathematics: An Exploratory Validation Study Focusing on Teaching Practices. Journal of Teacher Education, 67(3) 220-237. https://doi. org/10.1177/0022487116634168
Charalambous, C. Y., Hill, H. C. and Ball, D. L. (2011). Prospective teachers' learning to provide instructional explanations: How does it look and what might it take? Journal of $\mathrm{Ma}$ thematics Teacher Education, 14(6), 441-463. https://doi.org/10.1007/s10857-011-9182-z

Cramer, K. A., Post, T. R., and del Mas, R. C. (2002). Initial fraction learning by fourthand fifth-grade students: a comparison of the effects of using commercial curricula with the effects of using the rational number project curriculum. Journal for Research in Mathematics Education, 33(2), 111-144. https://doi. org/10.2307/749646

D'Ambrosio, B. S. and Mendonca-Campos, T. N. (1992). Pre-service teachers' representations of children's understanding of mathematical concepts: Conflicts and conflict resolution. Educational Studies in Mathematics, 23(3), 213-230. https://doi.org/10.1007/BF02309530

Depaepe, F., Torbeyns, J., Vermeersch, N., Janssens, D., Janssen, R., Kelchtermans, G., ... and Van Dooren, W. (2015). Teachers' content and pedagogical content knowledge on rational numbers: A comparison of prospective elementary and lower secondary school teachers. Teaching and teacher education, 47, 82-92. https://doi.org/10.1016/j.tate.2014.12.009

Domoney, B. (2001). Student teachers' understanding of rational numbers. En J. Winter (Ed.), Proceedings of the British Society for Research into Learning Mathematics, (Vol. 21, num. 3, pp. 13-18). BSRLM.

Isiksal, M. and Cakiroglu, E. (2011). The nature of prospective mathematics teachers' pedagogical content knowledge: The case of multiplication of fractions. Journal of Mathematics Teacher Education, 14(3), 213-230. https:// doi.org/10.1007/s10857-010-9160-x

Jacobson, E. and Izsák, A. (2015). Knowledge and motivation as mediators in mathematics teaching practice: The case of drawn models for fraction arithmetic. Journal of Mathematics Teacher Education, 18(5), 467-488. https:// doi.org/10.1007/s10857-015-9320-0

Jacobson, E., Lobato, J. and Orrill, C. H. (2018). Middle school teachers' use of mathematics to make sense of student solutions to proportional reasoning problems. International Journal of Science and Mathematics Education, 16, 1541-1559. https://doi.org/10.1007/ s10763-017-9845-Z 
Kang, R. and Liu, D. (2018). The importance of multiple representations of mathematical problems: Evidence from Chinese preservice elementary teachers' analysis of a learning goal. International Journal of Science and Mathematics Education, 16, 125-143. https:// doi.org/10.1007/s10763-016-9760-8

Kieren, T. E. (1993). The Learning of Fractions: Maturing in a Fraction. Ponencia presentada en la Conference Fraction Learning and Instruction, GA, Athens.

Klemer, A., Rapoport, S. and Lev-Zamir, H. (2018). The missing link in teachers' knowledge about common fractions division. International Journal of mathematical education in science and technology, 50(8), 1256-1272. https:// doi.org/10.1080/0020739X.2018.1522677

Krippendorff, K. (1990). Metodología de análisis de contenido. Teoría y práctica. Paidós.

Lamon, S. J. (2005). Teaching fractions and ratios for understanding: Essential content knowledge and instructional strategies for teachers $\left(2^{\text {nd }}\right.$ ed.). Lawrence Erlbaum Associates. https://doi.org/10.4324/9781410617132

Lee, M. Y. and Lee, J. E. (2019). Pre-service Teachers' Perceptions of the Use of Representations and Suggestions for Students' Incorrect Use. Eurasia Journal of Mathematics, Science and Technology Education, 15(9), em1745. https://doi.org/10.29333/ejmste/103055

Lee, S. J., Brown, R. E. and Orrill, C. H. (2011). Mathematics teachers' reasoning about fractions and decimals using drawn representations. Mathematical Thinking and Learning, 13(3), 198-220. https://doi.org/10.1080/10986065.2 011.564993

Li, Y. and Kulm, G. (2008). Knowledge and confidence of pre-service mathematics teachers: the case of fraction division. $Z D M, 40,833-843$. https://doi.org/10.1007/s11858-008-0148-2

Lo, J. and Grant, T. (2012). Preservice elementary teachers' conceptions of fractional units. En T. Y. Tso (Ed.), Proceedings of the 36th PME (Vol. 3, pp. 169-176). PME.

Lupiáñez, J. L. (2009). Expectativas de aprendizaje y planificación curricular en un programa de formación inicial de profesores de matemáticas de secundaria [Tesis doctoral]. Universidad de Granada, España. https:// fqm193.ugr.es/produccion-cientifica/tesis/ ver_detalles/5489/
Lupiáñez, J. L. (2013). Análisis didáctico: La planificación del aprendizaje desde una perspectiva curricular. En L. Rico, J. L. Lupiáñez y M. Molina (Eds.), Análisis didáctico en educación matemática (pp. 81-102). Comares.

Mack, N. K. (1990). Learning fractions with understanding: building on informal knowledge. Journal for Research in Mathematics Education, 21(1), 16-32. https://doi.org/10.5951/ jresematheduc.21.1.0016

Marks, R. (1990). Pedagogical Content Knowledge: From a Mathematical Case to a Modified Conception. Journal of Teacher Education, 41(3), 3-11. https://doi. org/10.1177/002248719004100302

Morris, A. K., Hiebert, J. and Spitzer, S. M. (2009). Mathematical knowledge for teaching in planning and evaluating instruction: What can preservice teacher learn? Journal for Research in Mathematics Education, 40(5), 491-529. https://doi.org/10.5951/ jresematheduc.40.5.0491

Movshovitz-Hadar N., Zaslavsky O. and Inbar S. (1987). An empirical classification model for errors in high school mathematics. Journal for Research in Mathematics Education, 18, 3-14. https://doi.org/10.5951/ jresematheduc.18.1.0003

Newton, K. J. (2008). An Extensive Analysis of Preservice Elementary Teachers' Knowledge of Fractions. American Educational Research Journal, 45(4), 1080-1110. https://doi. org/10.3102/0002831208320851

Rico, L. (2016). Matemática y análisis didáctico. En L. Rico y A. Moreno (Eds.), Elementos de didáctica de la matemática para el profesor de secundaria (pp. 85-100). Pirámide.

Rojas, N., Flores, P. and Carrillo, J. (2015). Conocimiento especializado de un profesor de matemáticas de Educación Primaria al enseñar los números racionales. Boletim de Educação Matemática, 29(51), 143-166. https://doi. org/10.1590/1980-4415v29n51a08

Rosli, R., Goldsby, D., Onwuegbuzie, A. J., Capraro, M. M., Capraro, R. M. and González, E. G. Y. (2020). Elementary preservice teachers' knowledge, perceptions, and attitudes towards fractions: A mixed-analysis. Journal on Mathematics Education, 11(1), 59-76. http://doi.org/10.22342/jme.11.1.9482.59-76. 
Sahin, O., Gökkurt, B. and Soylu, Y. (2016). Examining prospective mathematics teachers' pedagogical content knowledge on fractions in terms of students' mistakes. International Journal of Mathematical Education in Science and Technology, 47(4), 531-551. https:// doi.org/10.1080/0020739X.2015.1092178

Sánchez, M. (2011). A review of research trends in mathematics teacher education. PNA, 5(4), 129-145.

Socas, M. M. (1997). Dificultades, obstáculos y errores en el aprendizaje de las matemáticas en la educación secundaria. En L. Rico (Coord.), E. Castro, E. Castro, M. Coriat, A. Marín, L. Puig, et al., La educación matemática en la enseñanza secundaria (pp. 125-154). Horsori.

Stake, R. E. (2010). Investigación cualitativa: El estudio de cómo funcionan las cosas. The Guilford Press.

Steffe, L. P. and Olive, J. (1990). Constructing fractions in computer microworlds. In G. Booker, P. Cobb y T. N. de Mendicuti (Eds.), Proceedings of the 14th PME (pp. 59-66). CONACYT

Streefland,L.(1991). Fractions in Realistic Mathematics Education: A Paradigm of Developmental Research. Kluwer Academic Publishers. https://doi.org/10.1007/978-94-011-3168-1

Tirosh, D. (1999). Forms of mathematical knowledge: learning and teaching with understanding. En D. Tirosh (Ed.), Forms of mathematical knowledge (pp. 1-9). Springer. https://doi. org/10.1007/978-94-017-1584-3_1
Tröbst, S., Kleickmann, T., Depaepe, F., Heinze, A. and Kunter, M. (2019). Effects of instruction on pedagogical content knowledge about fractions in sixth-grade mathematics on content knowledge and pedagogical knowledge. Unterrichtswissenschaft, 47(1), 79-97. https://doi.org/10.1007/s42010-019-00041-y

Tröbst, S., Kleickmann, T., Heinze, A., Bernholt, A., Rink, R. and Kunter, M. (2018). Teacher knowledge experiment: Testing mechanisms underlying the formation of preservice elementary school teachers' pedagogical content knowledge concerning fractions and fractional arithmetic. Journal of Educational Psychology, 110(8), 1049-1065. https://doi. org/10.1037/edu0000260

Whitacre, I., Atabaş, Ş. and Findley, K. (2019). Exploring unfamiliar paths through familiar mathematical territory: Constraints and affordances in a preservice teacher's reasoning about fraction comparisons. The Journal of Mathematical Behavior, 53, 148-163. https:// doi.org/10.1016/j.jmathb.2018.06.006

Wu, H. H. (2018) The content knowledge mathematics teachers need. En Y. Li, W. Lewis, J. Madden (Eds.), Mathematics matters in education. Advances in STEM education (pp. 43-91). Springer. https://doi. org/10.1007/978-3-319-61434-2_4

\section{(c) $(1) \Theta \Theta$}

Conocimiento sobre fracciones de docentes de primaria en formación (Elena Castro-Rodríguez • Luis Rico) Uniciencia is protected by Attribution-NonCommercial-NoDerivs 3.0 Unported (CC BY-NC-ND 3.0) 